\title{
A Comparison of Anatolian and Azerbaijan Play With Song
}

\begin{abstract}
Yusuf HABİBOV*
İsmail SÖZEN**

ABSTRACT: As a part of child folklore, children play-songs have an important role in the psychological, physical, emotional, and moral development of children. In the present article, we studied the children folklore in relation to children play-songs between Anatolian Turks and Azerbaijan Turks. The planful solution of the research problem was a contemporary, important, and interesting issue. Both Anatolian and Azerbaijan children play-songs, play-styles, and the way they sing the songs were analyzed. Results showed that in both cultures, songs were singed single and/or dual forms; that when songs were singed in choir, the most basic forms (i.e., octave and unison octave) were used.
\end{abstract}

Key Words: Children folklore, children play folklore, plays with song

\section{SUMMARY}

The purpose of the present research is to compare, contrast and analyze children folklore and lullabies between Anatolian and Azerbaijan Turks in terms of plays with songs and the circumstances under which these are played out. By this, we hope to find out the similarities and differences in children folklore between these two related cultures. In addition, this study is important in displaying the multi-faceted importance of children plays in children's lives.

* Assist Prof. Dr.Gaziosmanpaşa University, Faculty of Education, yhabibov@ gop.edu.tr

** Ress. Assist., Gaziosmanpaşa University, Faculty of Education, isozen@gop.edu.tr 
Descriptive statistics was used in the methodological face of the study. As a result of the review of related literature, children plays which constitute an important part of children folklore are historically reviewed and plays were classified in terms of their functions, styles, equipments, time periods, and the persons who direct the plays. The population of the study included children plays that incorporated songs between Anatolian and Azerbaijan Turks. Therefore, the sample of the study included eight such plays that have been similar in the style and utterance. In the end. these eight songs were compared.

As a result of the analyses and comparisons, in terms of time, it was found that songs in both cultures are played different times of the year with the purpose of educating children and for fun. In terms of musical variables, the songs are played in the forms of solo, duet or dialog (solo-chorus, chorus- chorus). Under the circumstances where the songs are played in chorus, the simplest forms of vocalic tones such as octave, unison octave were used. Lastly, it was found that children plays had a very important role in different functions. Results are summarized below:

- Plays with songs have a crucial role in children's physical development.

- Plays with songs have a positive impact on children's language development.

- Plays with songs contribute positively to children's emotional and cognitive development.

- Plays with songs play an important role in children's social development.

- Plays with songs play important role in children's moral, esthetic, and cultural development.

- In addition to the above mentioned roles, plays with songs have an important place in the development of children's world views. 


\section{Anadolu ve Azerbaycan Türklerinin Çocuk Oyunlarının Karşılaştırılması}

Yusuf HABİBOV*

İsmail SÖZEN**

ÖZ: Çocuk folklorunun çocuk oyunu türleri, onların ruhi, manevi, psikolojik ve fiziksel gelişimindeki rolü sebebiyle çocuk hayatında çok önemli bir yere sahiptir.

$\mathrm{Bu}$ makalede; Anadolu Türkleri ile Azerbaycan Türklerinin çocuk folklorunun çocuk oyunu türünün araştırılmasını problem olarak önümüze koyduk. Problemin sistemli çözümünün güncelliğini, özelliğini ve önemini ön planda tuttuk. Araştırmalar sonucunda her iki Türk soylu halkın çocuk oyunlarını, oynanış tarzı ve söyleme tarzı bakımından analiz ederek, çocuk oyunlarının solo veya düet (solo koro, koro - koro) formlarında söylendiğini, ayrıca koro ile seslendirilen bölümlerde çoksesliliğin en sade formaları olan oktav, unison oktav elementlerinden yararlanıldığını ortaya koyduk .

Anahtar Sözcükler: Çocuk folkloru, çocuk oyun folkloru, şarkılı oyunlar

\section{GÍRIŞ}

Her iki Türk soylu halkın çocuk müzik folklorunun büyük bir bölümünü çocuk oyunları oluşturur. Çocuk oyunları, çocukların insan olarak şekillenmesi ve gelişimi için onlara doğumundan başlayarak tüm hayatları boyunca eşlik eder.

Çocuk oyunlarının araştırmaya başlanması çok eski tarihlere dayanır. $\mathrm{Bu}$ problemin çözülmesine, araştırılması ilk olarak 19. yy. başlarında

* Doç. Dr., Gaziosmanpaşa Üniversitesi Eğitim Fakültesi, yhabibov@ gop.edu.tr

** Arş. Gör., Gaziosmanpaşa Üniversitesi Eğitim Fakültesi, isozen@ gop.edu.tr 
başlamıştır. Bu probleme ilgi Batıda 1800'lü yıllarda başlarken, Doğuda ise bir süre gecikmiştir. Çocuk oyunlarının araştırılmasına hizmet eden çalışmalardan R. A. Bessonov'un "Çocuk Şarkıları" (1868), G. A. Pokrovski'nin “ Çocuk Oyunları" (2. bask1 1892), O. İ. Kapitsa' dan "Çocuk Folkloru" özellikle söz etmek gerekir (1928) vs. gösterebiliriz. Bizi ilgilendiren asıl problem G. A. Pokrovski'nin “Çocuk Oyunları” kitabında ayrıntılı olarak incelenmiştir. Öyle ki bu incelemelerin sonucunda çocuk oyunları iki büyük gruba ayrılmıştır. Bunlar: 1) İlkbahar ve yaz oyunları, 2) Sonbahar ve kış oyunları. Çocuk folklorunun sınıflandırılması konusunda O.İ. Kapitsa'nın hizmetlerinden özellikle söz etmek gerekir. Öyle ki, çocuk folklorunun oyunlar bölümünde oyunları, konusuna ve oynanıș zamanına göre dört gruba bölmüş ve "Mevsim Oyunları" terimini bilime kazandırmıştır. Çocuk oyunlarını şu şekilde sınıflandırmıştır: 1) İlkbahar oyunları, 2) Yaz oyunları, 3) Sonbahar oyunları, 4) Kış oyunları.

Azerbaycan Türklerinde çocuk folklorunun araştırılmasına 19. yy. sonu, 20. yy. başlarında başlanmıştır. Bu alanda Hasanbey Zerdabi'yi de özellikle kaydetmek gerekir. Çünkü 1897 'de o kendi imkanlarıyla çocuk şarkılarını toplamış, bastırmış ve okullara ücretsiz olarak dağıtmıştır. Bu sahadaki en önemli araştırmayı ise B. H. Hüseyinli yapmıştır. Azerbaycan çocuk folklorunu sınıflandıran, özellikle de çocuk oyunlarını ilk kez sınıflandıran B. Hüseyinli olmuştur. O, kendinden önceki bilim adamlarının sınıflandırma prensiplerini temel alarak Azerbaycan çocuk oyunlarını iki büyük gruba ayırmıştır: 1) Yaz oyunları, 2) Kış oyunları.

Kaydetmek gerekir ki yukarıda isimleri anılan araştırmalarda, esasen çocuk oyunlarının konusu ve oynanış biçimi analiz edilmiştir. B. Hüseyinli "Azerbaycan Çocuk Folkloru" makalesinde ise çocuk oyunlarını bir bütün olarak ele almış, çocuk oyunlarını konusu, oynanış biçimi, oynanış zamanı ve aynı zamanda müzikal açıdan incelemiştir.

Anadolu Türklerinde çocuk folklorunun araştırılması ise 1900'lü yıllarda başlamıştır. $\mathrm{Bu}$ sahada yapılan araştırmalardan Müşfika Abdülkadir'in "Maraş'ta Çocuk Oyunları" (1930), Yusuf Ziya Demircioğlu'nun “Anadolu'da Eski Çocuk Oyunları" (1934), Lütfi Ünsal'ın "Çorum'un Eski Çocuk Oyunları" (1943-1944), Ferruh Arsunar'ın "Türk Çocuk Oyunlarından Örnekler" (1955) ne nihayet Metin And'ın "Oyun ve Bügü” (1974) kitaplarını gösterebiliriz.

Anadolu Türklerinde çocuk folklorunun araştırılması problemi bilim adamı ve eğitimcileri devamlı düşündürmüş ve hala da düşündürmektedir. Yakın zamanda yapılan değerli araştırmalardan Hilmi Seyrek ve Muammer Sun'un "Çocuk Oyunları" (1991), Dr. Musa Baran'ın "Çocuk Oyunları" 
(1993) ve Yrd. Doç. Dr. Hatice Poyraz’'n “Okul Öncesi Dönemde Oyun ve Oyuncak" kitaplarını gösterebiliriz.

Ancak söylemeliyiz ki bu kitapların çoğunda çocuk oyunları konu, oynanış biçimi, kullanılan araç gereç bakımından analiz edilmiştir. Çocuk oyunlarının sinıflandırılmasını ise ilk kez Dr. Musa Baran I. Uluslararası Türk Folklor Seminerinde sunduğu "Folklorda Çocuk Oyunları" başlıklı bildiride kendi incelemesinin gereksinmesi için şöyle bir sınıflandırma yapmış ve her birinin yanlarına da bir örnek göstermiştir:

1) Bilmeceli Oyunlar (Me Sana?)

2) Şaşırmacalı Oyunlar (Yattı kalk)

3) Dilsiz Oyunlar (Ad bulmaca)

4) Resimli Oyunlar (Nokta nokta hat)

5) Ütümlü Oyunlar (Üç taş)

6) Tekerlemeli Oyunlar (Çatal matal)

7) Türkülü Oyunlar (Yağ satarım)

8) Sportif Oyunlar (Üç Dede- Tukuli)

9) Orta Oyunları [Seyirlik Oyun] (Saya oyunu)

10) Hayvanlarla Oyunlar (Kuş tutmaca)

11) Donatım Oyunlar (Kına vurmaç)

12) Gelişigüzel Oyunlar (Islamaç).

Dr. Musa Baran'ın sinıflandırma prensibini incelerken bu sınıflandırmanın çocuk oyunlarının sadece oynanış biçimine göre yapıldığını ortaya çıkartmış oluyoruz. Aynı zamanda kaydetmek gerekir ki, Dr. Musa Baran sınıflandırmasını devam ettirerek çocuk oyunlarını bir de işlevi bakımından üçe ayırmıştır; 1) Usu eğiten oyunlar, 2) Bedeni eğiten oyunlar, 3) İç duyguları eğiten oyunlar.

Anadolu Türk bilim adamları da çocuk oyunları ile ilgili araştırmalarında bu oyunları, konusu, oynanış biçimi ve kullanılan araç, gereç bakımından incelemişlerdir.

Bizim amacımız ise çocuk oyunlarını oynandığı zaman - mevsim bakımından sınıflandırmak ve müzikal açıdan analiz etmektir.

Anadolu Türklerinin çocuk oyunlarını ayrıntılı olarak inceleyerek, yani konusu, oynanış biçimi, kullanılan araç-gereç, müzikal açıdan ve esasen de oynandığı zaman şartlarına dikkate alarak, onları iki büyük gruba ayırabiliriz; 1 )Yaz oyunları, 2) Kış oyunları. 
Çocuk oyunları çocuk gelişiminde ikili rol oynar. Şöyle ki, bu oyunların bazıları çocukların konuşma becerisinin gelişimine, bazıları fiziksel gelişimine, bazıları yaratıcılığının gelişimine, bazıları ise dünya görüşlerini kavrama çerçevelerinin gelişimine ve ilerlemesine hizmet eder.

Şarkılı çocuk oyunlarının şiirlerini ve melodik yapısını analiz ederken, bu oyunların bazen yukarıda bahsettiğimiz çocuk gelişiminin herhangi bir özelliğine, bazen de birden çok gelişim özelliğine hizmet ettiğini ortaya çıkartmış oluruz. Ancak bu özelliklerin hepsi de çocukların ahlaki ve bilişsel gelişiminde önemli rol oynar.

Çocuk oyunlarının müzikal açıdan analizinde şarkılı çocuk oyunlarından yararlanacağımız için öncelikle şarkılı çocuk oyunlarından bahsetmek gerekir.

Şarkılı çocuk oyunlarını uygulayan kişiler bakımından ikiye ayırabiliriz:

1) Büyüklerin çocuklar için söyledikleri oyun şarkıları

2) Çocukların kendilerinin söyledikleri oyun şarkıları.

Yukarıda bahsettiğimiz birinci gruba dahil olan çocuk oyun şarkıları onların anneleri, babaları, nineleri, dedeleri ve nihayet akrabaları tarafından söylenir ve uygulanır. Bu gruba dahil olan oyun şarkılarının tek sesli ve solo olarak seslendirildiğini söyleyebiliriz. Birinci gruba dahil olan oyun şarkıları çocukların en küçük yaş döneminde söylenir.

İkinci gruba dahil olan oyun şarkıları ise çocukların kendileri tarafından seslendirilir. Okul öncesi (anasınıfı-anaokulu) dönemden başlayarak yetişkinlik dönemine kadar çocukların kendileri tarafından söylenir ve oynanır.

Her iki halkın çocuk folklorunda bulunan, çocukların kendileri tarafından seslendirilen oyun şarkıları, monolog ve diyalog (atışma) formunda söylenir. Monolog forma sahip oyun şarkıları çocuklar arasından seçilmiş bir kişi tarafından söylenir. Diyalog forma sahip oyun şarkıları ise bir kişi ile koro arasında ya da iki grup çocuk arasında yani iki koronun atışması formunda olabilir. Buraya kadar anlattıklarımız bize aşağıdaki fikri söylemek için zemin yaratıyor: Anadolu ve Azerbaycan Türklerinin çocuk folklorunun oyun şarkıları türüne dahil olan oyunların çoğunluğu, gruplakoroyla atışma ve solo ile koronun atışması formunda seslendirilir. 
Her iki halkın oyun şarkılarını aşağıdaki oyun şarkıları çeşitleri oluşturur:

1) Bilmece oyunları (Oyun tapmacalar)

a) Anadolu Türklerinin bilmece oyunlarından örnekler

"Yedi delikli tokmak".

"Küçücük çay tası içinde beyler aşı".

b) Azerbaycan Türklerinin bilmece oyunlarından örnekler

"Tap görüm”

"Bir guşum var bu boyda".

2) Sayışmacalar (Oyun saygaçları)

a) Anadolu Türklerinin sayışmacalarından örnekler

"Portakalı soydum"

"Eveleme develeme"

b) Azerbaycan Türklerinin sayışmacalarından örnekler

"Berbercan"

"Zöhre-Zibeyde"

3) Yanıltmaçlar (Celd danışıg)

a) Anadolu Türklerinin yanıltmaçlarından örnekler

"Beş boz yüklü beş boz eşek"

"Şu karşıda bir tarlam var"

b) Azerbaycan Türklerinin yanıltmaçlarından örnekler

"Başbarmag"

"Futbol"

4) Alay etme oyunları (Cirnatmalar )

a) Anadolu Türklerinin alay etme oyunlarından örnekler

"Aydede"

"Künü"

b) Azerbaycan Türklerinin alay etme oyunlarından örnekler

"Kepenek"

"Men elimi kesmişem"

"Tarda çalır"

"Yahşı ettim". 
Şarkılı çocuk oyunları yani bilmece oyunları, sayışmacalar, yanıltmaçlar ve alay etme oyunları müzikal bakımından çok sade ezgi kuruluşuna sahiptir. Bu ezgiler bazı durumlarda (yarı konuşma-yarı söyleme) mono recitatif tarzında seslendirilir. Bazen oyun şarkıları ritmik bakımından meydana gelmiş recitatif karakterli melodik bölümle başlar. Bu bölüm yavaş yavaş belirli ses yüksekliği elde ederek ritmik bakımdan meydana gelmiş açık bir ezgiye çevrilir. Bununla bağlantılı olarak B. Hüseyinli demiştir ki: "Genellikle çocuk folklorunda recitatif seslendirme tarzı sadece bir seslendirme tarzı değildir. Bu özellik bizim kanımızca çocukların kendi sanatsal fikir ve duygularını daha da açık bir şekilde yansıtma isteklerinden doğar. Elbette bu recitatif-declamation tarzının en karakteristik özelliğidir. Ancak bu recitatif seslendirme tarzında ezginin olmadığı anlamına gelmez. Recitatif seslendirme sırasında ses yüksekliği düşüncesinin gelişimini harekete geçirerek onun akıcı seslendirme tarzını kavramaya hazırlayan ikili, üçlü hatta bazen de dörtlü ses aralığı intonasyonları seslenir.

Bunun sonucunda da çocukların hayatlarının çeşitli alanlarını aydınlatan recitatif-declamation karakterde seslendirilen çocuk oyun şarkıları birçok amacın hayata geçirilmesine hizmet eder. Kanımızca bu oyun şarkıları çocukların düşüncelerinin şekillenmesinde, akli, fikri ve fiziksel gelişiminde, çocuğun manevi dünyasının şekillenmesinde tartışılmaz rol oynarlar.

Oyun şarkılarının seslendirilmesi sürecinde çocuklar yavaş yavaş yetkinleşir, onların şarkı söyleme ve konuşma yetenekleri gelişir, başka bir ifadeyle söylersek çocukların çok yönlü gelişimi için güzel ve verimli şartlar yaratır.

Daha önceden sözünü ettiğimiz solo ve grupla - koroyla söyleme tarzının Azerbaycan'daki en parlak örneği olarak okul öncesi çocuk grupları tarafından sevilerek ve ilgiyle seslendirilen "Bir guşum var bu boyda" bilmece oyununu gösterebiliriz.

Örnek 1

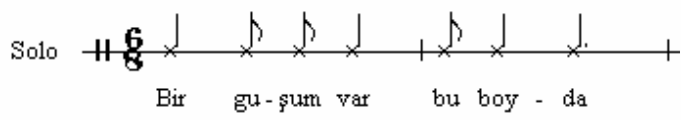

Bu bilmece oyunu oynak karaktere sahip olup erkek çocuklar arasında ve aşağıdaki şekilde oynanır: Oyuna katılan çocuklardan birisi gruptan ayrılarak onların karşısına geçer ve bilmeceyi sorar (yani solistlik 
fonksiyonunu yerine getirir). Aynı zamanda çeşitli el hareketleriyle (pantomim tarzında) kuşun ölçüsünü, onun gagasının formunu, gözlerinin rengini hatta tüylerinin rengini de gösterir. Kısacası zihnindeki kuşun özelliklerini ortaya koymuş olur. Oyundaki diğer çocuklar ise koro olarak çeşitli ses yüksekliğinde cevap verirler. Daha sonra solist bilmecenin ana sorusunu sorar.

Örnek 2

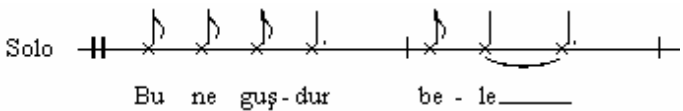

Sonra gruptan - korodan bir çocuk ortaya çıkar ve kuşun adını söyler.

Örnek 3

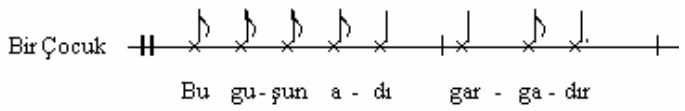

Eğer bu çocuk kuşun adını yanlış söylediyse o zaman bilmeceyi soran çocuk - solist oyunda çocuklara emreder.

Örnek 4

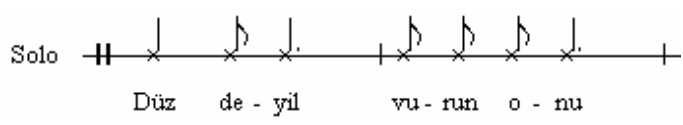

Bu emri duyan çocuklar yanlış cevap veren çocuğun üzerine atılırlar ve onu cezalandırırlar. Aksine eğer bu çocuk doğru cevap verirse o zaman yeni bilmece sorusu veren solistin yerine geçer, önceki solist ise gruba - koroya katılır. Böylelikle de bilmece oyunu yeniden başlar.

Anadolu Türklerinde ise solo ve grupla-koroyla söyleme tarzına örnek olarak okul öncesi çocukların severek oynadıkları "Pazara gidelim" isimli oyunu gösterebiliriz. 
Bu oyun aşağıdaki şekilde oynanır: Çocuklar bir sıralı safta dizilirler. Bunların 4 - 5 adım karşısında bir çocuk (solist) küçük adımlarla arkadaşlarına yaklaşır ve:
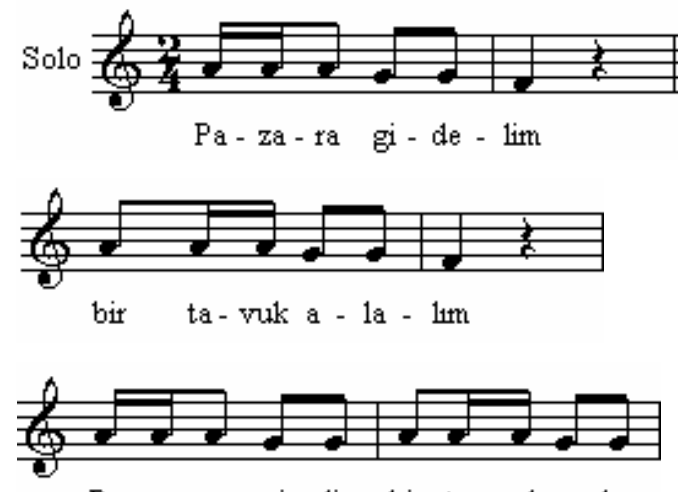

Pa-za-ra gi-dip bir ta-vuk a-lip

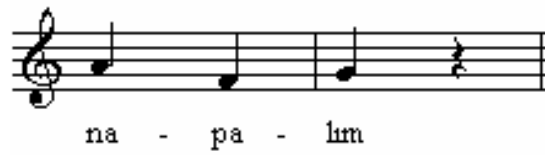

sözünü tamamlayınca, diğer çocuklar elele tutuşup, ebenin etrafında bir halka yaparken:

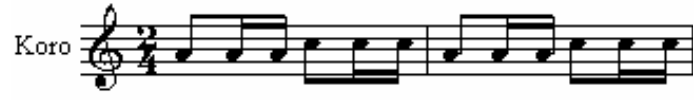

Ha-pu- tud hu- pu- tox ha- pu- tu hu- pu- tu-

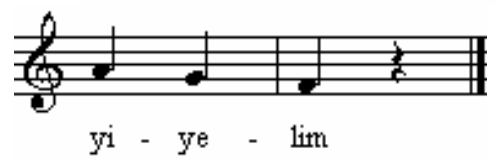

sözlerini söylerler.

Azerbaycan çocuk folklorunun örneklerinden grupla - koroyla söyleme tarzının özelliklerini kendisinde toplayan şarkılı oyunlardan "Benövşe" ("Menekşe") oyununu gösterebiliriz. Bu şarkılı oyun takvim merasiminde 
oynandığı için aslında yılın ilkbahar mevsiminde oynanır. Adından da anlaşılacağı gibi benövşe çiçeği ilkbahar başında açar. Bundan dolayı bu şarkılı oyun söylediğimiz gibi ilkbaharda oynanır. Kaydetmek gerekir ki benövşe oyunu sportif karakterli bir oyundur. Bu sebepten de okul öncesi ve okul çocuklarının fiziksel gelişimine çok olumlu etki eder.

Benövşe şarkılı oyunu aşağıdaki şekilde oynanır: - Oyunda iki grup çocuk vardır. Çocuklar el ele tutuşarak karşılıklı gelecek şekilde dizilirler. Gruplardan biri oyunu başlatarak sorar: - Benövşe? İkinci grup onlara cevap verir: Bende düşe. Sonra birinci grup yeniden sorar: - Bizden size kim düşe? İkinci grup çocuklar birinci grup çocuklardan birisinin adını söyler. İsmi söylenen çocuk ikinci grubun üzerine koşar. Eğer sırayı bozarsa o zaman ikinci gruptan bir çocuğu kendisiyle beraber grubuna götürür. Aksi halde, yani sırayı bozamazsa ikinci grupta kalır. Böylelikle oyunun sonunda hangi grupta daha çok çocuk kalırsa o grup galip gelmiş olur.

I. Grup

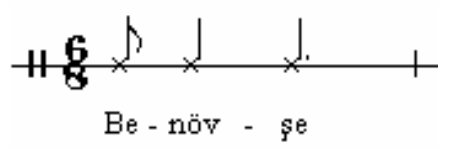

II. Grup

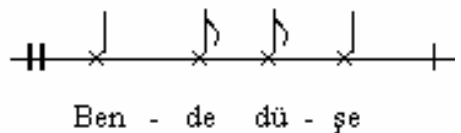

I. Grup

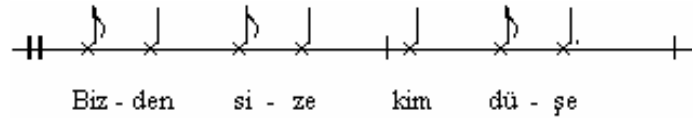

II. Grup

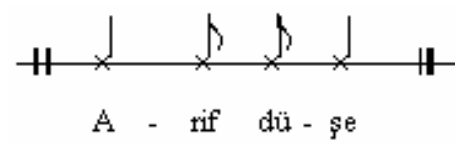


Anadolu Türklerinde de "Benövşe" oyunu "Menekșe" ya da "Bizden size kim düşe" ismiyle oynanmaktadır. Bu oyun aşağıdaki şekilde oynanmaktadır: Çocuklar iki gruba ayrılırlar. Daha sonra oyun sahası içinde karşılıklı gelecek şekilde yan yana dizilirler. Oyuncular el ele tutuşurlar. Oyunu başlatacak olan grupla karşı grup arasında şu tekerleme söylenir:

\section{Grup}

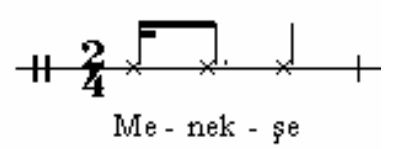

\section{Grup}

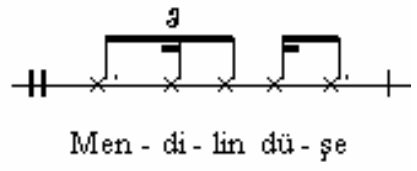

\section{Grup}

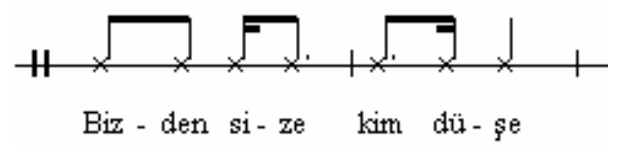

$\mathrm{Bu}$ tekerlemeden sonra II. Grup I. Gruptan birini seçer:

\section{Grup}

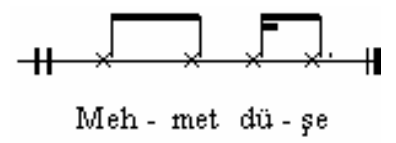

Seçilen çocuk koşarak karşı taraftaki oyucuların kenetlenmiş olan ellerini ayırmaya çalışır. Eğer ayırmayı başarırsa II. Gruptan bir kişiyi oyun dışı bırakır. Fakat ayıramayacak olursa kendi oyun dışı kalır. Bu oyun dışı 
kalan oyuncular kenarda otururlar. Eğer kendi takımından biri karşı takımdakilerden birinin kenetlenmiş ellerini ayırmayı başarırsa kazanan oyuncu kenarda oturan arkadaşlarından birini oyuna yeniden alır. Oyun böylece devam eder.

İki oyunun oynanış biçimleri arasında yaptığımız karşılaştırma sonucunda bir farka rastlamadık. Ancak oyunun son bölümünde bazı farklılıklar göze çarpmakta:

- Azerbaycan'da oynanan varyantta ismi söylenen çocuk ikinci grubun üzerine koşar. Eğer sırayı bozarsa o zaman ikinci gruptan bir çocuğu kendisiyle beraber grubuna götürür. Aksi halde, yani sırayı bozamazsa ikinci grupta kalır.

- Anadolu'da oynanan varyantta ise seçilen çocuk koşarak karş1 taraftaki oyucuların kenetlenmiş olan ellerini ayırmaya çalışır. Eğer ayırmayı başarırsa II. Gruptan bir kişiyi oyun dışı bırakır. Fakat ayıramayacak olursa kendi oyun dışı kalır. Eğer kendi takımından biri karşı takımdakilerden birinin kenetlenmiş ellerini ayırmayı başarırsa kazanan oyuncu kenarda oturan arkadaşlarından birini oyuna yeniden alır.

Eski Azerbaycanlıların hayat hakkındaki ilk anlayışları inançların, dinin ilk formlarında ; totemizm, Şamanizm, antropomorfizm, animizm, panteizm ve başkalarında kendisini göstermiştir. Bu inançların izlerine eski mevsim merasim şarkılarında (mesela yağmura, güneşe, yeşil sümbüle hitap etmek), çocuk sayışmacalarında ve eski destan, masallarda bu günde rastlayabiliriz.

Eski insanların bu gibi tasavvurları ile en fazla takvim merasimleri ve bu merasimlere eşlik eden şark1 ve danslarda karşılaşabiliriz.

Eski Azerbaycan'da (dünyanın başka eski halklarında olduğu gibi) yılın bir mevsiminin başkası ile değişmesi, bir mevsimin ölmesi diğerinin dirilmesi gibi düşünülürdü Zaman geçtikçe bu düşüncelerin geleneği takvim merasimi formunu alıyor. Bu merasimlerin eski Yunan merasim geleneği "Dionis"le benzer yönlerinden Azerbaycan sözlü edebiyatının araştırmacısı M. Tahmasib kaydediyor ki; 'Eski Yunanistan'da, Azerbaycan'da olduğu gibi kışın ilkbahar ile değişmesi tabiatın ölüp dirilmesi gibi tasavvur edilirdi”.

Yılın iki mevsiminin kış ile ilkbaharın, tabiatın iki zıt kuvvetinin tartışması hakkında biz, eski edebiyat örneklerinde, birçok doğu halklarının tarihi ve sanat esri olan "Avesta"da ${ }^{1}$ karşılaşırız. Aynı zamanda "Avesta"da,

${ }^{1}$ Avesta Zerdüştlük devrinin mukaddes kitaplar topluluğudur. Bu din eski devirlerin orta asırlarında İran, Orta Doğu, Azerbaycan ve Afganistan'da yayılmıştır. Bu günde Hindistan'da 
bu merasimlerde şarkıların Azerbaycan'da olduğu gibi toplu halde söylenmesinden de bahsedilir. "Avesta"nın en büyük araştırmacılarından Z. A. Ragozin yazıyor: "Tanrı tarafından kurbanın kabul edilmesi için, kurban merasiminde iştirak eden topluluk belirli kurallara riayet ederdi. Bu sırada toplu olarak, mukaddes konuları belirli ses yüksekliğinde söylerlerdi.

Eski Azerbaycan'da solo ve topluluk halinde koro ile şarkı söyleme unsurlarını kendisinde toplayan takvim merasimlerinden birisi "Baharın karşılanmasıdır". Kaynaklardan birisinde, "Bahar Bayramı"nın Zerdüştlük devrinden birkaç asır önce kutlandığı söylenmektedir. Bu bayram birkaç bin yıl geçmesine rağmen kendi manasını yitirmemiştir.

Baharın karşılanması şerefine yukarıda bahsettiğimiz merasim büyük tantana ile kutlanırdı. Bu merasimde tizden, ince ses yüksekliği ile söylenen konuşmalar, daha doğrusu recitatifle beraber müzik, baharın şerefine söylenen marşlar büyük yer tutardı. "Baharın karşılanması" merasiminde bizim için ilginç olan durum, marşların kahinler tarafından koro ile söyleniyor olmasıdır.

Yılın iki mevsiminin tartışmasını (kışla ilkbahar) kendisinde açıkça gösteren mevsim merasimlerinden birisi de "Kosa kosa" (Köse köse) oyunudur. "Kosa kosa" mevsim oyunu da çok eski geçmişe sahiptir. "Kosa kosa" oyununun takvimle bağlantısı, bu oyunun sadece bahar bayramı şenliklerinde oynanması, daha net bir ifadeyle bu oyunun "Nevruz" bayramı günlerinde oynanıyor olmasıdır.

"Kosa kosa" oyunun söz ve müzik materyali analiz edildiğinde, onun bünyesinde halk şarkısı ve koreografik sanatlar gibi birçok türün unsurları görülebilir. Bizim dikkatimizi, bu oyunun seslendirme tarzında solo (yardımcının şarkıları), müzik diyalogu (halk ve yardımcı) ve ayrıca recitasiya formunda (halkın sonda topluluk halinde söylediği şarkı) koro ile söylenen şarkı çekmektedir. Bizim için bu oyunda unison ve koro recitasiyası formunda seslendirme tarzının olması en önemli durumdur ${ }^{2}$.

Farslar bu dine ibadet ederler. Çok asırlık tarihe sahip sözlü edebiyattan Sasaniler (III. VII. yy.) devrinde yazıya aktarılmış. "Avesta"nın içeriği 21 kitaptan ibarettir. Bize bunların ancak dörtte biri ulaşmıştır.

${ }^{2}$ Prof. Dr. B. H. Hüseyinli 1965 yılında "Kosa kosa” oyununu Daşkesan bölgesinin Kültür sarayının sanat topluluğunun söylemesinden notaya almıştır. 
Kosa'nın yardımcisı

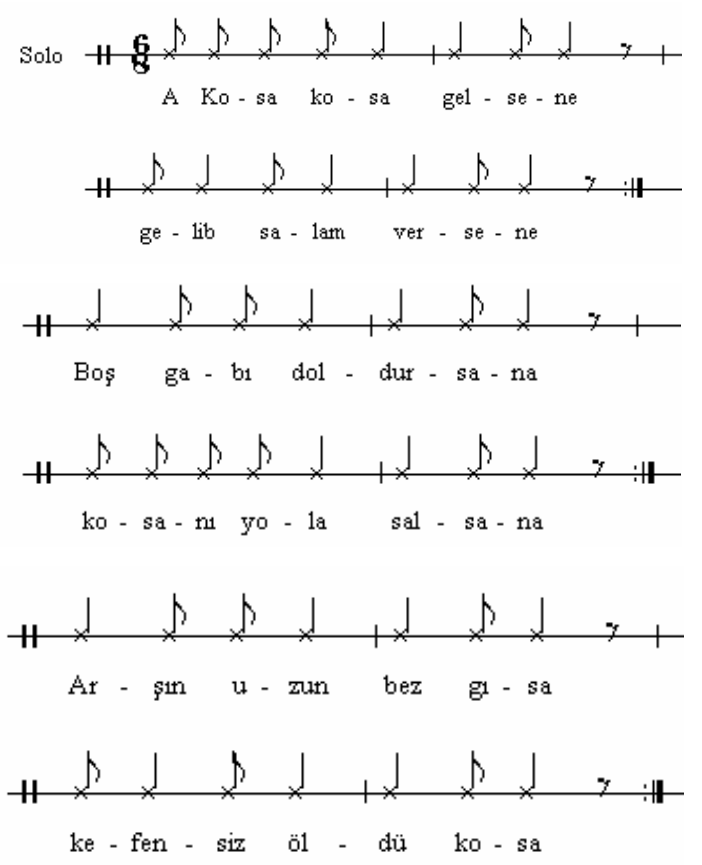

Halk

Karo

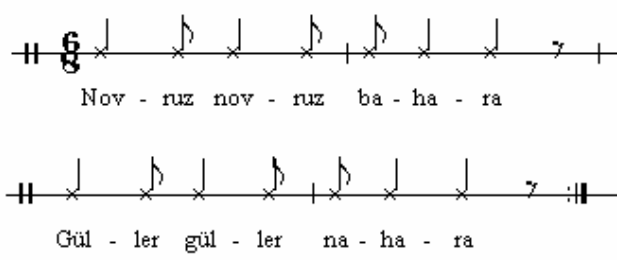

"Kosa kosa “ oyunun başka bir varyantı ile Anadolu'da "Köse Köse" ismiyle karşılaşıyoruz. Oyun aşağıdaki şekilde oynanır: Erkek kılığına girmiş bir kadın odanın ortasında bir mindere boylu boyunca uzanır, üzerine bir çarşaf örtülür. Tef çalınır. Bu Köse'dir. Kösenin çevresinde 8 - 10 kadın (sözde bunlar Köse'nin eşleridir) aşağıdaki sözleri söyleyerek dönerler: 
Kösenin karıları

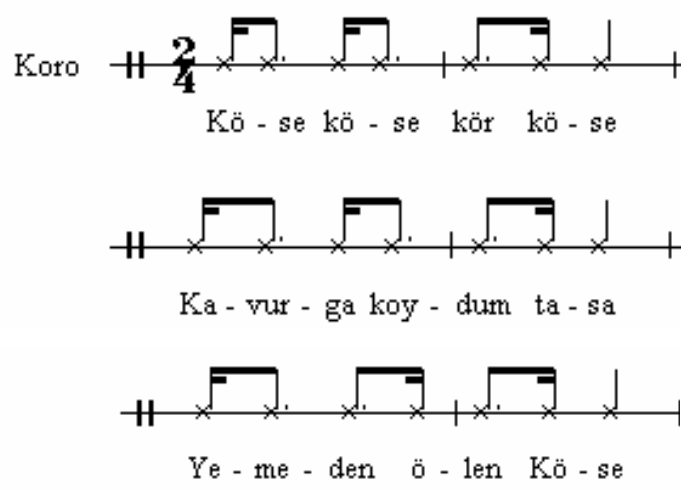

Kadınlar bu sözleri söylerken bir yandan da ölüm döşeğindeki Köse’den aşağıdakine benzeyen isteklerde bulunurlar:

Köse'nin I. Karısı

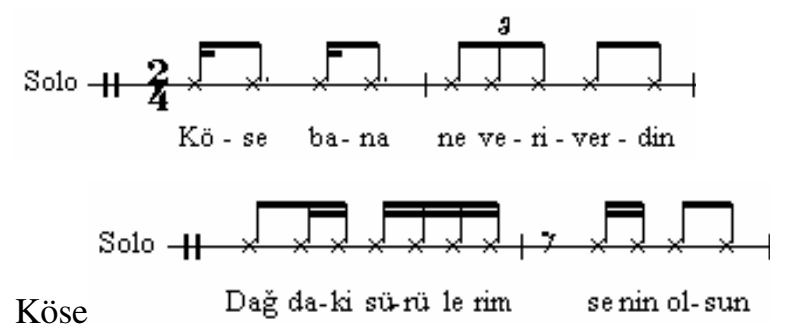

Köse'nin II. Karısı

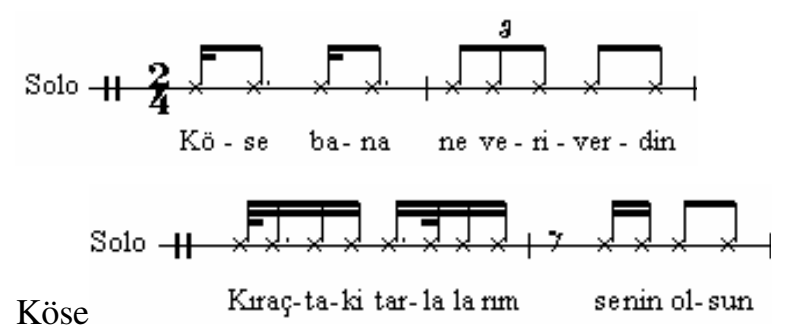

Köse' nin III. Karısı

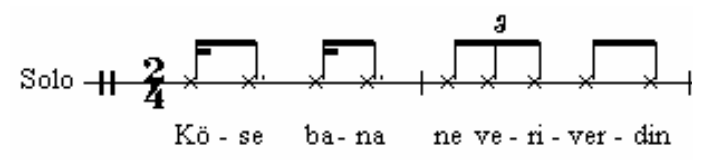




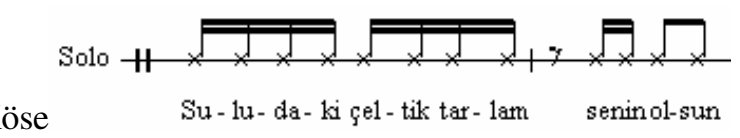

Böylece kösenin çevresinde dolanan kadınların hepsi Köse'den bir şeyler koparırlar. Birbirine "oh, bana verdiği şey seninkinden daha iyi Köse beni senden daha çok sever" biçiminde nispet eder, seyredenleri güldürürler. Bunlardan sonra Köse ölür. Kadınlar hareketlerle Köse'yi soyup sözde yıkarlar. Kadınların kimi ölümünden üzülüp ağlar, kimi de sevinir. Köse'yi her biri bir yanından tutarak odadan çıkarırlar, oyun biter.

Görüldüğü gibi Anadolu'da görülen "Köse köse" oyunu Azerbaycan'daki varyantı gibi mevsimlerin tartışmasını anlatmaz. Bununla bağlantılı olarak mevsime bağlı oynanan bir oyun değildir.

Eski Azerbaycan'da takvim merasimlerinin başka varyantları da uygulanırmış. $\mathrm{Bu}$ merasimler yılın bir mevsiminin ölmesi diğerinin doğmasını canlandırır. $\mathrm{Bu}$ tarz merasimlerden birisi de ilkbaharın başlangıcında uygulanan "Semeni" dir ${ }^{3}$.

\section{SEMENI}
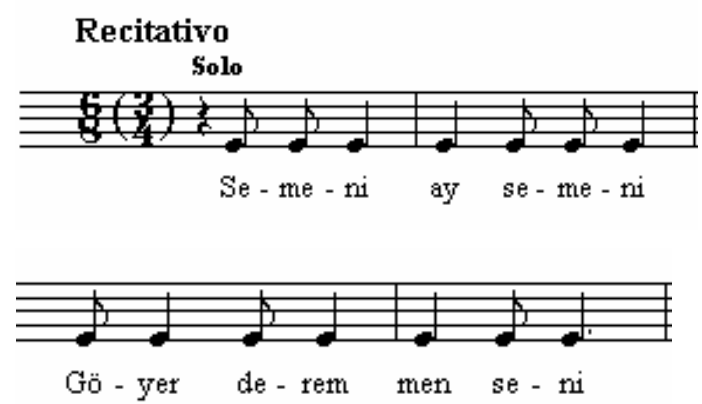

${ }^{3}$ Yeni olmuş buğdaya Azerbaycan'da “Semeni” denir. 

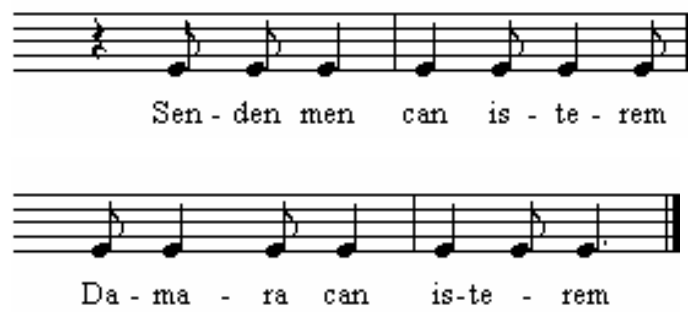

Vokal sanatının solo ve toplu şarkı söyleme türlerinden yararlanılan eski mevsim merasimlerine "Godu godu", "Hıdır İlyas" ve "Kesvenç"i de ilave edebiliriz. "Godu godu" şarkıları, erkek veya oğlanlar tarafından koro ile unison olarak komşu evleri gezerken söylenir. Bu ananede, en önemli durum erkek korosunun söylemesidir. Bu ise bize birçok halklarda olan, baharın karșılanması merasiminde söylenen șarkıları hatırlatır. "Godu godu" şarkılarının yüksekten söylenmesi (f) ise İ. Kvitki'nin yazdığı gibi, eski insanların tabiat kuvvetlerine etki etme isteğinden kaynaklanır.

Yılın kış ve ilkbahar mevsiminde söylenen, kız fal açma şarkılarını da mevsim merasim grubuna dahil etmek gerekir. Bu tür şarkılardan "Gum gadir", "Son Çarşamba", "Nevruz Bayramı"nı gösterebiliriz. Halk arasında bu tür şarkılar, yani fal açma merasimi şarkıları genel bir isim altında toplanır. Örnek olarak "Vesfihal" ve "Can - gülüm”"ü kaydetmek gerekir. Bahsedilen merasim şarkıları solo ve grupla söylenir. Bu şarkılar söylenirken nakaratın her misrasından sonra koro unison olarak "can gülüm can can" sözlerini röpriz gibi tekrar eder.

\section{CAN GÜLÜM CAN CAN}

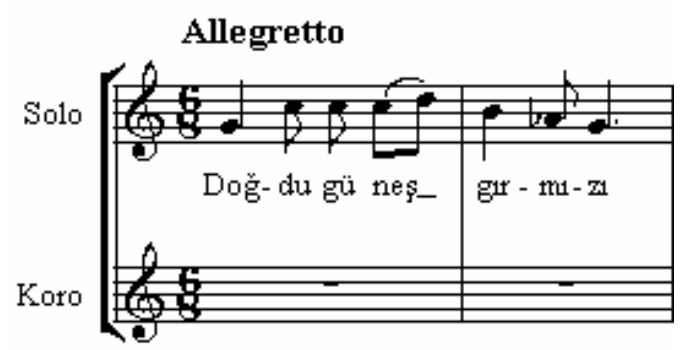



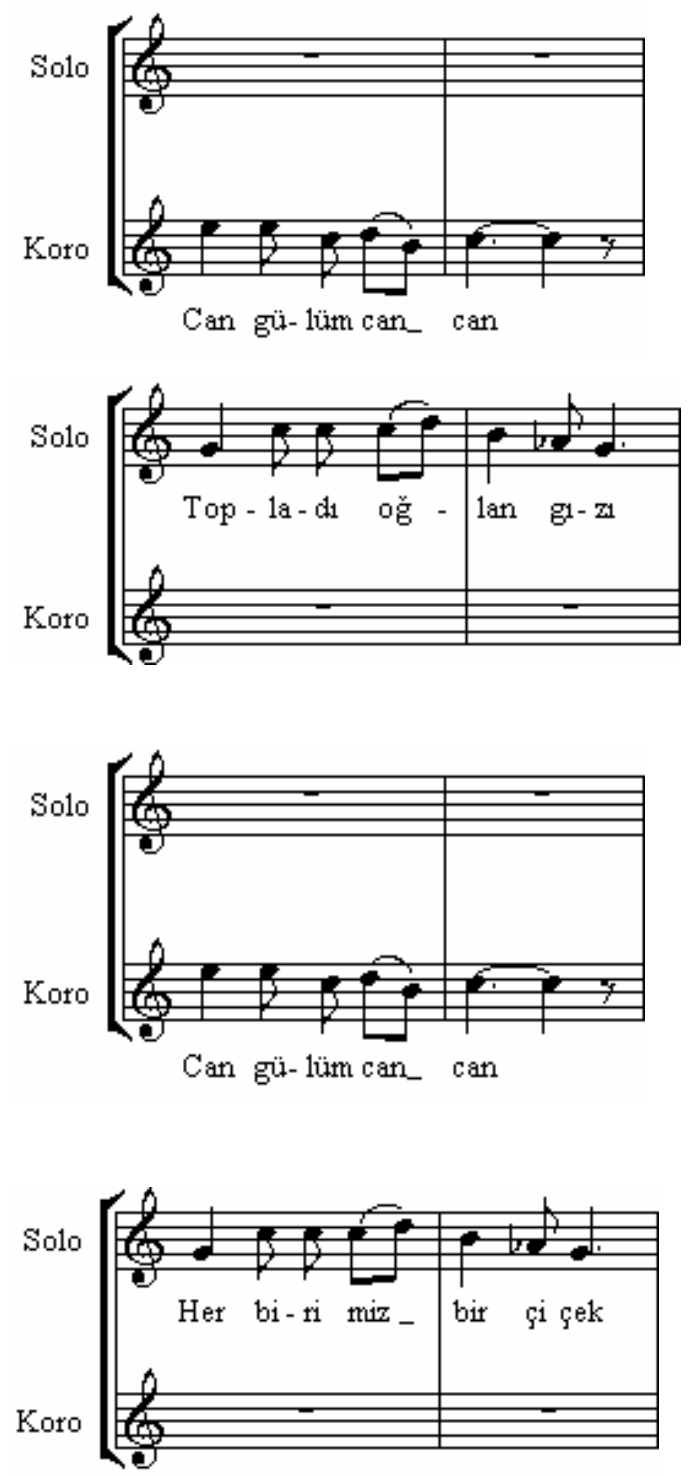

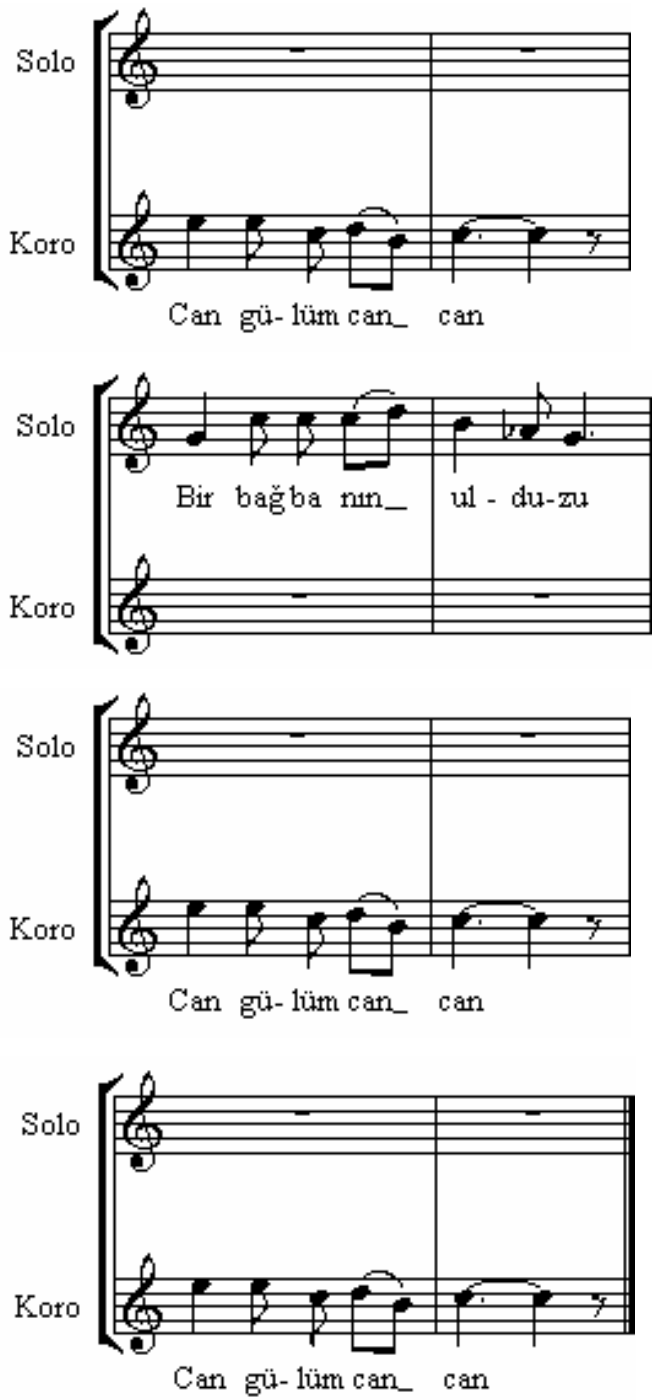

Takvim merasim oyun ve şarkılarının eski tarihinden bahsederken onların ilkel kuruluşa sahip müzik ve söz metnine de dikkat etmek gerekir.

Kanımızca eski takvim merasim şarkı ve ananelerin, içeriğini oluşturan şiirler özel kurallara sahip olan şiir formu olmuştur. Zaman geçtikçe, ananevi mevsim ve genel merasimlerde, Türk dilli halkların sözlü edebiyatında 
yaygın bir şiirsel form olan "Bayatı" dan (Mani) yararlanılmıştır. Bundan dolayı halk müziğinin (folklorumuzun) çeşitli türlerinde, takvim ve aile merasim şarkılarında da manilerle çok sık karşılaşırız. Kaydetmek gerekir ki, günümüze kadar gelen merasim şarkılarının sözleri de "bayatı" formundadır.

\section{SONUÇ}

Azerbaycan Türkleri ile Anadolu Türklerinin çocuk oyunlarından bir kısmını analiz ederek aşağıdaki sonuçları elde etmiş olduk:

- Her iki halka ait bu şarkılı oyunlar hem yılın herhangi bir mevsimi dahilinde hem de mevsim dışında çocukların eğitim ve eğlence zamanlarında oynanir.

- Bu şarkılı oyunlar solo, düet - diyalog (solo - koro, koro - koro) formunda seslendirilme tarzına sahiptirler. Koro ile seslendirilen bölümlerde çoksesliliğin en sade formları olan oktav, unison oktav unsurlarından yararlanılır. Verilen örneklerde bu formlar açıkça kendilerini gösterirler.

- Her iki halkın şarkılı çocuk oyunları çocuk hayatında çok yönlü fonksiyon taşırlar:

a) Şarkılı oyunlar çocukların fiziksel gelişimininde tartışılmaz rol oynarlar.

b) Şarkılı oyunlar çocukların konuşma yeteneklerini geliştirirler.

c) Şarkılı oyunlar çocukların duygusal ve zihinsel açıdan gelişimine katkıda bulunurlar.

d) Şarkılı oyunlar çocukların sosyal açıdan gelişiminde önemli rol oynarlar.

e) Şarkılı oyunlar çocukların manevi, estetik ve kültürel yönden gelişimine katkıda bulunurlar.

f) Şarkılı oyunlar yukarıdaki özelliklerle beraber çocukların dünya görüşlerinin şekillenmesi ve gelişiminde de önemli rol oynarlar. 


\section{KAYNAKLAR}

Aliyeva, N. K. (1968). Azerbaycan Halk Musikisinin Çokseslilik Elementleri Hakkında. Azerbaycan Incesanatı Dergisi, 54-66.

Akandere, M. (2003). Eğitici Okul Oyunlar (1. Baskı). Ankara: Nobel Basımevi.

And, M. (1974). Oyun ve Bügü (1. Baskı). İstanbul: Baha Matbaası.

Brudnıy, V. M. (1968). Obriyad Vçera i Segodniya. Moskova: Nauka.

Güneş, H. (2003). Çocuk Oyunlar (1. Baskl). Ankara: Anı Yayıncılık.

Hüseyinli, B. H. (1980). Çocuk Musiki Folklorunun Tesnifatı. SSSR Halklarının Musiki Komisyonu Dergisi, 36-40.

Kapitsa, O. İ. (1928). Detski Folklor. Leningrad.

Komisyon. (1968). Azerbaycan Folklorunun Antologiyası. Bakü: Elmler Akademiyası Neşriyatı.

Komisyon. (1981). Azerbaycan Halk Musikisi. Bakü: Elmler Akademiyas1 Neşriyatı.

Musa Baran. Uluslararası Türk Folklor Semineri 'Folklorda çocuk oyunlar'

Pokrovski, G. A. (1892). Detskiye İgrı (2. Baskl). Moskova.

Poyraz, H. (1999). Okul Öncesi Dönemde Oyun ve Oyuncak (1. Baskı). Ankara: Anı Yayınc1lık.

Sel, R. (2000). Okul Öncesi Çocuklarına Oyunlar-Rondlar (1. Baskı). İstanbul: Yapa Yaincilık.

Zemsovski, İ. İ. (1975). Melodika Kalendarnıh Pesen. Leningrad: Muzıka. 